\title{
Alternative Systems of Medicines: Are they Placebos?
}

\author{
Srinivasan MS* \\ Transpersonal Psychology of Indian Yoga and the Spiritual Genius of India, India
}

Submission: January 17, 2018; Published: August 21, 2018

*Corresponding author: Srinivasan MS, Transpersonal Psychology of Indian Yoga and the Spiritual Genius of India, India;

Email: srinivasan@aurosociety.org

Keywords: Alternative systems of medicine; Placebo; Yogic psychology; faith-cares; Subconscious Influences; ASM

\section{Perspective}

Recently, some questions are raised regarding the scientific basis of alternative systems of medicine like homeopathy, which we will call in this article as ASM. Are they based on scientific foundations or just "faith-cares" or placebos? This article examines this question in the light of yogic psychology.

\section{The Placebo Effect}

Oxford dictionary defines the "placebo" as a "medicine given to patients to make them happier or more confident rather than for any physical effect". For example, the doctor injects distilled water or sugar syrup to a patient and tells her that he has given a very powerful medicine which will cure her in a short time. And it actually cures. The healing factor here is the faith of the patient that she was given a wonderful medicine and it will cure her. There are influential sections in medicine and media, probably supported by the powerful drug industry, which are trying to undermine the validity of ASM and dismiss them as mere placebos. For example, an editorial in the Economic Times with the title "No Alternative" argues that there is no alternative to the allopathic systems of medicine because all other systems are just placebos. Some research findings by a reputed medical researcher are cited to support the conclusion.

Faith is undoubtedly a great healing force. If we have a deep and strong faith in the self-healing powers of our own body or the power of the divine grace or both, along with a positive, optimistic attitude, they alone are enough to heal all ailments. But most of us don't have such a faith. We have a greater faith in the medicine, and this faith in the medicine, and the system of medicine - which is the basis of the placebo-effect- is a major factor in healing. We have to include here faith in the doctor and his personality. A doctor who radiates confidence and infuses hope in the patient enhances the possibility of cure.

\section{The Subconscious Influences}

However, placebo-effect is much more subtle than a mere belief in the surface conscious mind. There are long established collective suggestions or impressions in the sub-conscious which can contradict or reinforce the beliefs of the conscious mind. For example, the long-term domination of the allopathic system of medicine and the idea it is based on scientific principles and research, is a strong impression in the sub-conscious mind of our modern psyche. Thus, allopathic system of medicine has a stronger placebo effect than ASM's which are generally perceived to be unscientific. As a result, the statement of the allopathic doctor "doctor says" has an almost scriptural authority on the modern patient. Even those who accept, appreciate or opt for ASM or criticize allopathic medicine, cannot entirely kick-off the sub-conscious influence of the allopathic system. As Dr. Alok Pandey, a former psychiatrist in Indian Air Force, points out: "Now whether it is legitimate or not that it is a fact that most human beings today put their trust almost exclusively in the allopathic paradigm. I have witnessed a number of persons who would otherwise scoff at allopathy but easily believe in its prognostications. It is not their fault. It is simply the power of sub-conscious mind that is working" [1].

Apart from or added on to all these factors, we have the potent power of the media with its conscious and sub-conscious influence. When a well-known popular media like Economic Times states in its editorial that ASM are just placebos, its impact on the minds of its readers can be extensive. Even some people who follow a spiritual path and vision and skeptical of allopathy repeat like a parrot this kind of media reports on ASM without any critical thinking or considering the validity of alternative viewpoints in favor of ASM. So, we have to enquire how far and to what extent this type of damaging reports on ASM are valid. To 
answer this question, we have to examine the main differences between the vision and methodology of ASM and allopathy.

\section{The Subtle Healing}

The traditional allopathic approach to healing is exclusively or predominantly physical, based on the direct, material effect of chemicals or radiation on the disease like for example such and such chemicals or radiation can destroy cancer cell through such and such chemical reaction. This system of medicine admits nothing behind or beyond material forces and the physical body. But the approach of ASM is based on an intuition into the deeper and subtler forces beyond the material energies and other bodies behind the physical. The founders of ASM perceived a subtle physical body behind the gross body and a vital energy-body behind the subtle physical body and a mental and spiritual body behind the vital. The healing process in ASM acts on the subtle or energy body or the seed of disease in these subtler bodies to bring about the cure in the physical body.

For example, Ayurveda talks about "doshas" as the sources of diseases. But these doshas are not material entities but discordant energies in the vital body causing disease in the physical body. The Ayurvedic healing process - through diet, fasting, medicine and changes in the life style - aims at curing

DOI: 10.19080/JCMAH.2018.07.555703 the diseases in the physical body by correcting the doshas in the subtle vital body. Similarly, homeopathy speaks of "miasm" as a deep-rooted source of illness possibly in the subtle or vital body. The tiny, concentrated capsules of homeopathy acts on the subtle or vial bodies. In response to a question or homeopathy on how such infinitesimal dosses can any have any effect on the human body, Sri Aurobindo said- "Sometimes infinitesimal is more powerful than the mass; it approaches more and more the subtle state and from the physical goes into a dynamic state and acts vitally" [2]. So, the traditional kind of scientific research based on discovering the material cause of things cannot discern the effectiveness of ASM. For example, the chemical constitution of a homeopathic medicine doesn't have any direct curative action on a disease because it acts on the subtle body. So, when a medical scientist of the allopathic system tries to find the curative process of a homeopathic medicine in terms of direct chemical effects he may not find anything and come to the conclusion that it is just a placebo.

\section{References}

1. Alok Pandey (2012) Patient at the Cross roads, Auropublications, Puducherry, P. 115.

2. Purani AB (1943) Evening Talks with Sri Aurobindo, Sri Aurobindo Ashram, Puducherry, P.208.

Your next submission with Juniper Publishers will reach you the below assets

- Quality Editorial service

- Swift Peer Review

- Reprints availability

- E-prints Service

- Manuscript Podcast for convenient understanding

- Global attainment for your research

- Manuscript accessibility in different formats

( Pdf, E-pub, Full Text, Audio)

- Unceasing customer service

Track the below URL for one-step submission https://juniperpublishers.com/online-submission.php 